Journal of Management and Development Studies

Volume: 30 , Issue 1, 24-36

(C) 2021 Nepal Administrative Staff College

Article Link: https://doi.org/10.3126/jmds.v30i1.36348

https://www.nasc.org.np/journals/all

ISSN 2392-4896 online/ ISSN 2392-4888 print

\title{
Public expenditure in Nepal: A case of transportation sector
}

\author{
Narayan Prasad Ghimire \\ Texas International College \\ nntghmr02@gmail.com
}

\section{Introduction}

\begin{abstract}
The rapid growth in public investment in various sectors was assumed after decades of conflict and an unstable political situation. With the declaration of the Federal Republic, Nepal is going to embark on accelerated economic growth. This has somewhat caused concerns among policymakers of its implication for economic growth. And the government investment in transportation infrastructure is one of the core strategies, called the 'infrastructure of infrastructures'. The main aim of this study is, therefore, to explain the relationship between economic growth and public expenditure in the transportation sector in Nepal. Primarily, this study has focused on the distinction of expenditures in the five-year development plans in three systems (Panchayat, Democratic, and Republic). This study used time series data collected between 1975 and 2016. The statistical and econometric tools have been used for the study. The result shows that the trend of government investment on public expenditure has increased in the Republic system. This study reveals that the variables are stationary on the first difference. The obtained regression model is satisfactory by diagnostic tests (errors are normally distributed, no serial correlation, and homoscedastic). The data explain the positive and significant influence of Transportation Capital Expenditure on Gross Domestic Product, and, hence, it is contributing to economic growth. Furthermore, the results show short-run unidirectional causation from Transportation Capital Expenditure to Gross Domestic Product.
\end{abstract}

Keywords: Public Expenditure, Transportation, Economic Growth, Nepal

Economic growth has been one of the central tenets among the theoretical as well as analytical researchers; however, little consensus has been reached on the inquiry into the factors that increase or deter economic growth. After the long term of political instability and the decade of 
conflict, Nepal is venturing into accelerated economic growth. For accelerated economic growth, transport sector development has been recognised as one of the essential strategies. Transport sector development is an intense work of government since private investors abnegate to invest in transport infrastructure projects due to their long gestation period and due to high start-up costs (Shikha, 2016). Hence, public investment has a great degree of attention for researchers. Investment in the public sector in specific assets, whether through central or local governments or publicly owned industries or corporations, defines the public investment. For Wegrich (2014), "the general definition of the public sector includes government ownership or control rather than mere function and thereby includes, for example, the exercise of the public authority or the enactment of public policy" (para. 2).

Furthermore, public investment has arisen historically from the need to provide certain goods, infrastructure, or services that are deemed to be of vital national interest. Public investment has tended to increase as a consequence of industrialisation and corresponding demands for new infrastructure to facilitate the growth of urban communities. Hence, there is a positive relationship between public investment and growth. Stiglitz (2000) also points out these two factors as a critical subject for development analysis and there exists an inter-relation between them. Barro and Sala-I-Martin (1992) suggested the direct effects of public expenditure on infrastructure on the growth of the economy. The majority of the research, as noted above, supports a significant and positive relationship between public infrastructure and economic growth. Nevertheless, there is an element of risk involved for government policymakers who depend on such research to predict economic outcomes from various strategies. Aschaur (1989) found the positive and significant relationship between public infrastructure and economic growth; however, the impact of public infrastructure on economic growth in Nepal is not clear. Hence, the objective of this research is to examine the relationship between the transportation expenditure of public investment and economic growth in the context of Nepal.

In the context of Nepal, expenditure on developmental works, particularly in the transportation sector, is not in a satisfactory condition (Bhagat, 2017). It has been observed that the transportation expenditure to Gross Domestic Product (GDP) ratio of Nepal is less than 3 percent (Nepal Rastra Bank [NRB], 2017a) which is not contributing to GDP. Hence the study highlights the short-run or long-run relationship between the variables under study.

\section{Literature review}

There is an extensive review of economic growth related to public investment. Growth economists like Paul M Romer and Robert Lucas Jr. attempted to explain the technological progress and carved an emergence of the new theory of growth known as endogenous growth theory. The endogenous growth theory explicitly tries to model technology (that is, looks into the determinants of technology) rather than assuming it to be exogenous. Mostly, economic growth comes from technological progress, which is essentially the ability of an economic organisation to utilise its productive resources more effectively over time. Much of this ability comes from the process of learning to operate newly created production facilities in a more productive way or more generally from learning to cope with rapid changes in the structure of production which industrial progress must imply (Verbeck, 2000). 
Dhungel and Bista (2015) dealt with the Stanley Please Hypothesis and stated that the cause and sources of increasing government expenditure in the least developed countries are associated with its effectiveness and overall impact on the economy. Increasing the tax rate implies more expenditure increase in government consumption. So, please effect is relevant in developing countries. Nevertheless, Dhungel and Bista (2015) also criticize that higher government expenditure might harm the economy through the negative externality in the private expenditure and through crowding out effect. As per the Rahn Curve, 20 percent of GDP is taken as the optimum level of public expenditure (Pettinger, 2018).

\section{Public Investment: International context}

Ghali (1997) found no consistent evidence that government spending increases Saudi Arabia's per capita output growth. Therefore, the fiscal policy aimed at controlling the budget deficit in Saudi Arabia must consider shrinking the size of government spending and limiting its role in the economy.

Concerning public investment, transportation, infrastructure, and growth in Poland, Rutkowski (2009) proved higher public investment stimulates growth through statistical evidence and suggested further investment in the area of transportation with introducing distortionary taxes that support the recovery. This result is supported by Nurudeen and Usman (2010) who stated government expenditure on transportation and communication are the determinants of economic growth; however, expenditures on other sectors cause negative implications. Such evidence shows that higher investment is obligatory for transportation and communication to create an enabling environment for businesses to strive. However, Ebiringa and Charles-Anyaogu (2012) found that the impact of the transportation sector expenditure is negative while other variables possess a positive relationship. Moreover, investment should be diverted from economic infrastructure (transportation and communication, health, education) to social infrastructure in the motive to gain an increasing growth rate. The study used the Principal Component Analysis and Vector Error Correction Model (VECM) for the statistical analysis and decision-making process. The insignificant impact of economic and social infrastructure rate on economic growth rate is according to what the theory suggests: there is sufficient gestation period required for the infrastructure investment to affect economic growth (Younis, 2016).

Okoro (2013) investigated the impact of government spending and found a long-run relationship with investment in roads, power supply, transport, and communication and suggested recurrent expenditure mostly on issues that attract economic growth.

\section{Public investment: Nepali context}

Kanel (1988) claimed that the expansion of the public expenditure had taken place only after 1970. For Kanel, development expenditure grows faster than the recurrent expenditure, and the elasticity coefficient for total development expenditure, economic services, and social services concerning per capita income is more than unity. Also, Shrestha (2009) found as long as the productivity of the expenditure is higher than the interest rate, an increase in expenditure will increase the growth rate in an economy and physical infrastructure plays a very important role to enhance economic growth by promoting private market production. However, Aryal (2011) claimed an insignificant relationship between public expenditure and economic growth and the share of public expenditure 
on the GDP is increasing over time, the share of current expenditure in the total expenditure is higher than the capital expenditure on the total expenditure.

\section{Pride projects in Nepal}

The Federal Democratic Republic of Nepal is facing an infrastructure deficit. The infrastructure sector is underdeveloped though various five-year plans are formulated to address it. The infrastructure sector is suffering from a huge infrastructural gap. So, to drive the state towards prosperity, there are some ongoing pride projects in the ground or air and road transportation.

\section{Railways}

First of all, East-West Electric Railway Project is a government initiated mega project of 420 kilometres. Detailed Project Report for the Butwal-Gaddachauki section has been completed (Shrestha \& Shahi, 2014). Also, 70 percent of track opening that includes 30 kilometres for Bardibash-Lalbandi sector of Bardibash-Simara section has been completed. This project has covered 22 kilometres of the Itahari-Biratnagar section which has been planned for the fiscal year 2016-17 (Ministry of Physical Planning and Works, 2015).

\section{Airports}

Nijgadh/Dhumberwana International Airport is a proposed airport development project in southeastern Nepal designed to relieve expected capacity restraints at Tribhuvan International Airport in Kathmandu. The proposed airport site lies at $150 \mathrm{~km}$ from Kathmandu by road. It is expected that the airport will feature two parallel runways and will be capable of handling 15 million passengers annually (Sahayogee, 2019). The airport area coverage is 3627 ropanis of land in Pokhara Lekhnath Metropolitan City. The project covers 2500 meters of the runway as per the International Civil Aviation Organisation (ICAO) norms set for 4D airports (Koirala, 2017). Another airport as the pride project is the Gautam Buddha Airport also known as Bhairahawa Airport, an airport in Siddharthanagar, a municipality in Rupandehi District in Lumbini Province. It has one runway designated surface measuring 1,510 by 34 meters (Pathak, 2018).

\section{Highways}

Puspalal (Mid-Hill) Highway Project bends its way from Chiyabhanjyang of Panchathar in the East to Jhulaghat of Baitadi in the Far-west - a distance of 1776 km. The Lumbini Kankai Surya Construction had been in charge of the construction on the $12 \mathrm{~km}$ Halesi-Bijule section, Lama Nagarjun Trishuli had been entrusted with blacktopping the $12 \mathrm{~km}$ Bijule-Hurlung and $11.4 \mathrm{~km}$ Hurlung-Diktel road sections (National Planning Commission, 2011). Secondly, Postal Highway also called Hulaki Rajmarg runs across the Terai region of Nepal, from Bhadrapur in the east to Dodhara in the west. The total length of the road project is $1,792.42 \mathrm{~km}$. The selected sites are Gaurigunj of Jhapa and Rangeli of Morang in Province 1, Mahagadhimai of Bara, Ishwarpur of Sarlahi, Shambhunath of Saptari, and Balwa and Sarpallo of Mahottari in Province 2. Likewise, Rajapur of Bardiya and Bardaghat of Nawalparasi in Lumbini Province, and Belauri of Kanchanpur and Bhajani Trishakti of Kailali in Sudurpachim Province (Baral, 2017). Furthermore, to facilitates the promotion of an improved core road network between the capital city and Terai, the Government of Nepal has launched the Kathmandu-Terai Fast Track Project for the area coverage of $72.6 \mathrm{~km}$. The fast track runs from Kathmandu - Lalitpur - Makawanpur and up to Nijgadh in Bara district. The project has 
proposed to build a $1.6 \mathrm{~km}$ long tunnel in Thingan of Makawanpur on public-private partnership (Dahal et al., 2014).

By studying the above literature, it is concluded that there has not been an empirical study on public investment in Nepal about transportation expenditure. However, there are some studies conducted in the international arena. In the national context, most of the studies on this field are like 'nature and trend of public expenditure', 'relationship between public expenditure on economic growth' and so on for education, health sectors and as well as overall expenditures with the growth. But no empirical study exists on the public expenditure in case of the transportation sector in Nepal. There are some studies on the relationship between government expenditure and economic growth; however, until now no study has been conducted to check the investments in transportation that leads to growth. Hence, this study examines government expenditure in the transportation sector for economic growth in Nepal by employing a regression model.

\section{Study method}

The study is primarily based on secondary data. Only annual time-series data set has been used for analysis. To analyse the relationship between public investment in the transportation sector and economic growth, the study has used the annual data from July 1975 to July 2016 (end of the fiscal year of Nepal). The corresponding data are used from a quarterly economic bulletin (NRB, 2017b), current macroeconomic and financial situation (NRB, 2017c), and various economic surveys published by the Ministry of Finance (Economic Survey). Gross Domestic Product is taken as the proxy of Economic Growth. Capital expenditure and recurrent expenditure in the transportation sector are the proxies for public investment. However, data have been used in the natural logarithm form rather than in original form for some analysis.

\section{Model specification}

The underlying analytical framework for the nexus of economic growth is the HD model which links output growth to aggregate investment in a linear function. The rate of output growth in the HD model can be captured in the production function with capital as the sole input. Therefore, the production function of developing countries can take the following form $Y(t)=f(K(t)$ ) (Xayavong, 2007). Hence, the methodology for the study is of the linear regression model in which GDP acts as the function of Government Expenditures and the source of revenue. So, the model is in the form of

$$
Y=f\left(X_{1}, X_{2}\right)+u
$$

Hence, the linear econometric model takes the form of:

$$
\begin{aligned}
& R G D P_{t}=\beta_{0}+\beta_{1} R T C_{t}+\beta_{2} R T R_{2}+u_{t} \\
& \text { Where RGDP = Real Gross Domestic Product } \\
& \qquad \mathrm{RTC}=\text { Real Capital Expenditure of transportation } \\
& \text { RTR }=\text { Real Recurrent Expenditure transportation } \\
& \mathrm{u}=\text { Stochastic error term }
\end{aligned}
$$


Note: All the variables are expressed in a real term using CPI value and values are expressed as the Natural Logarithms.

The variables in the trivariate regression model are all converted into real-term by applying the following formula, and the basic price is adjusted taking the base year 2000/01.

Real value $=\frac{\text { Nominal Value }}{\text { Consumer Price Index }} \times 100, i=1 \ldots \ldots n$

To carry out the modelling on time-series data, it becomes obligatory to scrutinize the stationary status of the variables. The method used is Augmented Dickey-Fuller (ADF) proposed by Dickey and Fuller (1979). The methodology further adopted the technique of cointegration regression developed by Johansen (1988) to inspect the long-term, or equilibrium, of the relationship among the variables in the model. Then for the short-run and long-run possibility, the use of VAR and VECM have been used. This article ran VAR or VECM after the integration of variables in the first difference, however De and Dkhar (2018) performed ARDL (Significant for equations having variably integrated to I (1) or I (0) simultaneously. All the time series modelling has been performed by E-Views 10 student version and interpreted. The trend and structure are addressed using Microsoft Excel 2016 version.

\section{Results and discussion}

\section{Descriptive analysis}

Table 1 shows the public expenditure in different regimes with trend and structure. The trend of government transportation capital expenditure, in different political periods, is illustrated in Table 1.

Table 1: Trend of public expenditure (Average)

\begin{tabular}{llll}
\hline Regime & RTC* & RTR $^{\wedge}$ & RGDP^^ \\
\hline Panchayat (1975-1991) & 68553.3 & 4184.765 & 3277426 \\
Democracy (1992-2006) & 78718.5 & 4001.332 & 5967857 \\
Republic (2007-2016) & 122123.6 & 20170.62 & 6584701 \\
\hline
\end{tabular}

Note: * Real Transportation Capital, ^Real Transportation Recurrent, ^^^ Real Gross Domestic Product

Amount in Rs. In Million

Table 1 illustrates the increment of real government transportation expenditure from Panchayat to Republic regime. The data for the panchayat system, democratic system, and republic system were taken from the time of 1975 to 1991, 1992 to 2006, and 2007 to 2016 respectively. RTC is much higher in Republic, which is an average 122123.6, than democratic and Panchayat systems, which are 78718.5 and 68553.3 respectively. Similarly, the RGDP is the highest in the case of the Republic regime (6584701) followed by Democracy (5967857) and Panchayat (3277426). However, RTR shows different scenarios. The RTR expenditure is highest in the republic (20170.62) followed by the Panchayat (4184.765) and the Democratic (4001.332) systems. 
Figure 1: Trend and Nature of Real GDP of Nepal

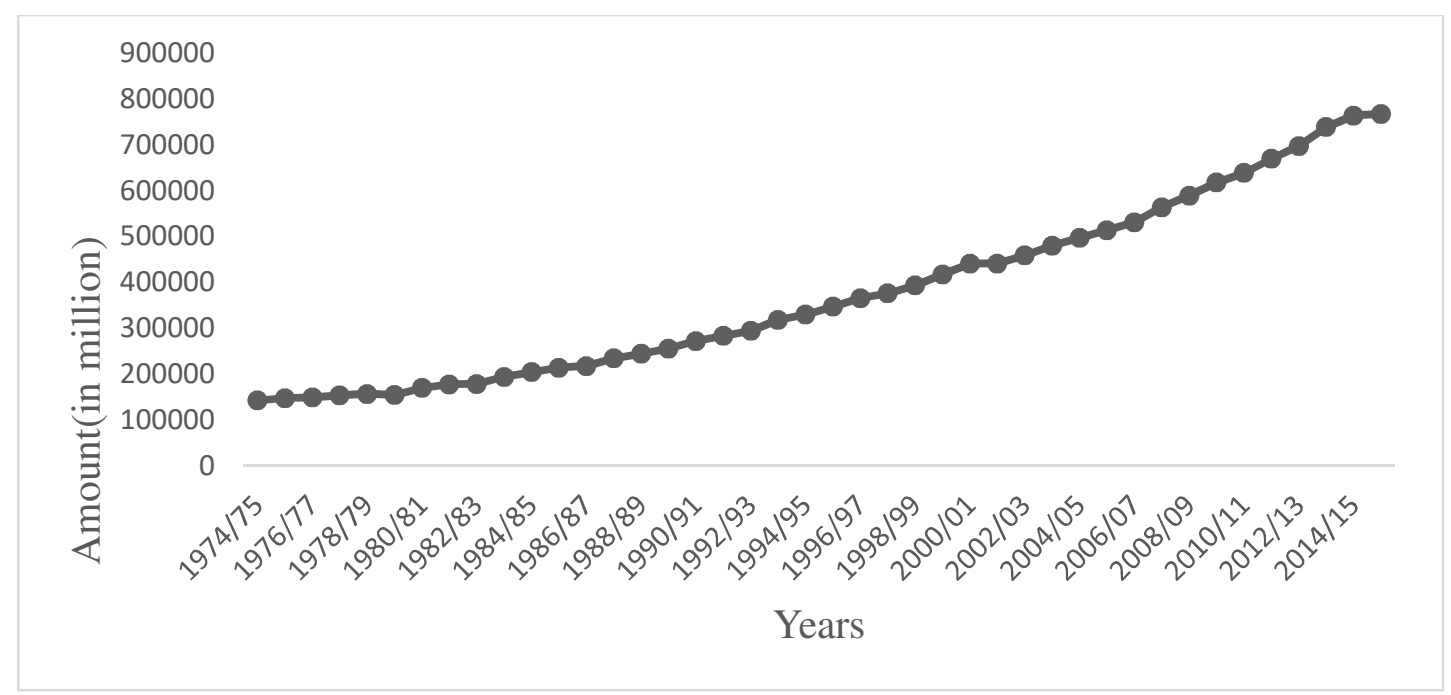

Figure 1 shows that the real GDP is constantly increasing. The real GDP was approx. 1.5 million in 1975 , whilst in the year 1979 (4.5 million), there was a break in the increasing trend. However, the decreasing trend did not last long and recovered overtime to reach 7.5 million in 2014-15.

Figure 2: Trend and nature of RTC and RTR

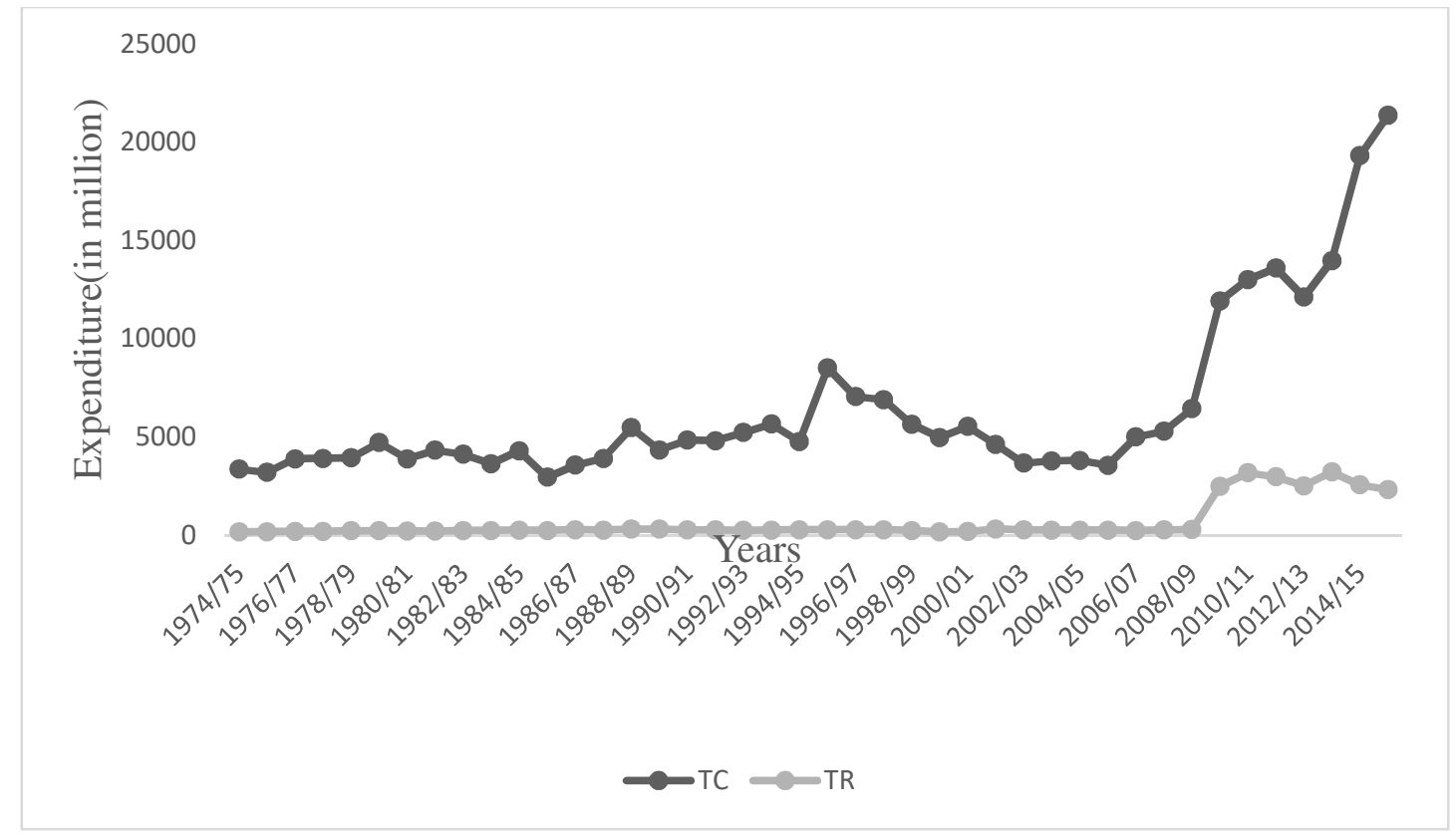

Figure 2 illustrates the trend and structure of RTC and RTR investments made by the government. The trend shows that there was a minimum expenditure in both cases of RTC and RTR. In 1974- 
75, the capital seemed to have been less than 5 million in expenditure. This expenditure remains below 5 million until 2006-07. A small increment in 1994-95 was seen. However, a sudden decrease was seen in 1996-97. And eventually, there was a rise in capital expenditure. This is the positive aspect that there is an investment in the transportation sector. This shows that there were minimal investments by the government in the Panchayat regime. However, after the democratic system, government investment in the transportation sector has become rapid.

\section{The unit root test}

In the Augmented Dickey-Fuller test- RGDP, RTC, and RTR do not have a unit root in the level model, indicating that these variables are not stationary either with a constant without a trend or with a constant with a trend because all absolute values of the t-statistics are greater than the critical value which implies that we cannot reject the null hypothesis $\left(\mathrm{H}_{0}\right)$. Therefore, the variables have a unit root, and $\left(\mathrm{H}_{0}\right)$ is accepted. However, when the variables are converted to the first difference, all first differenced variables, that is, D (GDP 1)), and the remaining variables in the model become stationary, meaning that they do not have a unit root. Therefore, we shall use the first differenced variables in our model because of their stationary nature (see Table 2).

Table 2: ADF test for the variables

\begin{tabular}{lllllll}
\hline ADF & \multirow{2}{*}{ Gross Domestic Product } & \multicolumn{2}{l}{$\begin{array}{l}\text { Capital } \\
\text { Transportation }\end{array}$} & \multicolumn{2}{l}{$\begin{array}{l}\text { Expenditure } \\
\text { Recurrent } \\
\text { Transportation }\end{array}$} \\
\hline & Original & $\begin{array}{l}\text { Ist } \\
\text { Difference }\end{array}$ & Original & $\begin{array}{l}\text { Ist } \\
\text { Difference }\end{array}$ & Original & \multicolumn{1}{l}{$\begin{array}{l}\text { Ist } \\
\text { Difference }\end{array}$} \\
\hline None & 11.8302 & -0.2696 & 1.3869 & $-7.009^{* * *}$ & 1.0355 & $-5.5910^{* * *}$ \\
Constant & 0.0244 & $-7.2558^{* * *}$ & -0.0751 & $-7.3289^{* * *}$ & -0.5838 & $-5.6767^{* * *}$ \\
$\begin{array}{l}\text { Constant } \\
\text { and trend }\end{array}$ & -2.8198 & $-5.8539 * * *$ & -1.2692 & $-7.4956^{* * *}$ & -3.0670 & $-5.6903^{* * *}$ \\
\hline
\end{tabular}

Note: ***denotes variables stationary at a 5 percent level of significance.

To ensure the stationary of time series data, the Augmented Dickey-Fuller unit root test of all variables has been done and found that the variables are integrated into I (1). Simiyu (2015) also pointed out that data are stationary after first differencing. Yet some of the variables integrated to I (0) (De \& Dkhar, 2018). In the unit Root Test above, the results are integrated with I (1). This suggests implying either Vector Auto Regressive (VAR) or Vector Error Correction Model (VECM). For choosing the appropriate model, co-integration test is formulated. In case there is no cointegration between variables, using VECM leads to misspecification. Rather using VAR will be appropriate. To run the co-integration, the optimal lag length should be decided.

\section{Lag length selection}

Optimal lag length selection criteria are used for ensuring that the model is not misspecified (Enders, 1995, as cited in Simiyu, 2015). Various methods are used in literature for the optimal lag length criteria like likelihood ratio (LR), Final Prediction Error (FPE), Akaike information criterion (AIC), Schwartz Information Criteria (SBIC), and Hannan Quinn Information Criteria (HQIC). The result of the lag length in this model is presented in Table 3. 
Table 3: Result of lag length selection criteria

\begin{tabular}{lllllll}
\hline Lag & Log L & LR & FPE & AIC & SBIC & HQIC \\
\hline 0 & -62.1963 & & 0.006206 & 3.431385 & 3.560669 & 3.477383 \\
1 & 90.80068 & $273.7841^{*}$ & $3.18 \mathrm{e}-06^{*}$ & $-4.147404^{*}$ & $-3.630272^{*}$ & $-3.963412^{*}$ \\
2 & 94.87428 & 6.646409 & $4.16 \mathrm{e}-06$ & -3.888120 & -2.983138 & -3.566134 \\
3 & 97.78247 & 4.285750 & $5.89 \mathrm{e}-06$ & -3.567498 & -2.274667 & -3.107519 \\
4 & 105.7903 & 10.53660 & $6.51 \mathrm{e}-06$ & -3.515278 & -1.834597 & -2.917305 \\
\hline
\end{tabular}

The lowest information criterion for LR, FPE, AIC, SBIC, and HQIC is lag 1 which is shown by the $\mathrm{p}$-value. So, further analysis is performed under lag 1 of the variables.

\section{Johansen cointegration}

Johansen cointegration is run for the choice between models for showing the long-run or shortrun relationship between variables. If there exists a long-run relationship, the test for the long run (i.e., Vector Error Correction Mechanism) will be used to find the direction of long run whereas the existence of short-run will prefer VAR model.

Table 4: Results of Johnsen co-integration

\begin{tabular}{lllllllll}
\hline $\begin{array}{l}\text { Hypothesized } \\
\text { no. of CE(s) }\end{array}$ & \multicolumn{9}{l}{ Trace statistics } & \begin{tabular}{l} 
Max \\
\cline { 2 - 8 }
\end{tabular} & $\begin{array}{l}\text { Trace } \\
\text { Statistics }\end{array}$ & p-value & $\begin{array}{l}\text { Maximum Eigen-value } \\
\text { Eigen } \\
\text { Value }\end{array}$ & p-value & $\begin{array}{l}\text { Trace } \\
\text { Statistics }\end{array}$ & p-value & $\begin{array}{l}\text { Max } \\
\text { Eigen } \\
\text { Value }\end{array}$ & $p$-value \\
\hline None & 0.1835 & 10.9750 & 29.7971 & 0.9618 & 0.183502 & 8.109248 & 21.13162 & 0.8969 \\
At most 1 & 0.0691 & 2.8658 & 15.4947 & 0.9726 & 0.06913 & 2.865499 & 14.26460 & 0.9553 \\
At most 2 & $6.57 \mathrm{E}-06$ & 0.0003 & 3.8415 & 0.9891 & $6.57 \mathrm{E}-06$ & 0.000263 & 3.841466 & 0.9891 \\
\hline
\end{tabular}

Source: Author's Calculation through E-Views 10.

Since the $p$-value of none of the co-integration is greater than 5 , which implies the acceptance of the null hypothesis, there are no co-integrating equations. Alternatively, in the Unrestricted Cointegration Rank Test (Trace), trace statistics is less than a critical value which accepts the null hypothesis. Further, the maximum Eigenvalue test also signifies the rejection of the alternative hypothesis and acceptance of the alternative hypothesis (see Table 4).

\section{Granger causality test/ block Exogeneity Wald test}

The absence of co-integration among the variables justified the existence of a short-run relationship between the variables and hence it is appropriate to use the VAR Model. Granger Casualty/Block Exogeneity Wald test is performed for the causal relationship between the variables. However, Simiyu (2015) found a long-run relationship on Johansen Co-integration and performed VECM.

The short-run causal relationship between the variables of the bivariate models are found to be not co-integrated in the long-run. The variables as TC (Transportation Capital) and TR (Transportation 
Recurrent) are tested in the short run with GDP. However, it is a mandatory task for this study to go for the short-run causality investigation of the variables.

Table 5: Result of granger causality/block exogeneity wald tests

\begin{tabular}{lllllll}
\hline Model & $\begin{array}{l}\text { Hypothesis } \\
\text { (Null Hypothesis) }\end{array}$ & $\begin{array}{l}\text { Dependent } \\
\text { Variable }\end{array}$ & $\begin{array}{l}\text { Explanatory } \\
\text { Variable }\end{array}$ & X'-Stat & P-value & $\begin{array}{l}\text { Direction of } \\
\text { Causality }\end{array}$ \\
\hline 1 & $\begin{array}{l}\text { D(RTC) and D (RTR) } \\
\text { cannot cause D (RGDP) }\end{array}$ & D(RGDP) & D(RTC), D (RTR) & 1.9726 & 0.373 & $\begin{array}{l}\text { Both D(RGDP) and } \\
\text { D(RTR)can cause D } \\
\text { (RTC) }\end{array}$ \\
2 & $\begin{array}{l}\text { D (RGDP) and DRTR } \\
\text { cannot cause D (RTC) }\end{array}$ & D (RTC) & D(RGDP), D (RTR) & 7.2898 & 0.026 & \\
& $\begin{array}{l}\text { D (RGDP) and D (RTC) } \\
\text { cannot cause D (RTR) }\end{array}$ & D (RTR) & D(RGDP), D (RTC) & 0.1892 & 0.910 & \\
& & & & & \\
\hline
\end{tabular}

Table 5 shows the results of VAR tests for short-run causality. It is found that D (RTC) and D (RTR) jointly cannot cause $D(R G D P)$. However, there exists a short-run causality between $D(R G D P)$ and $D(R T R)$ with $D(R T C)$. The $D(R G D P)$ and $D(R T R)$ simultaneously can cause $D(R T C)$. Hence, the causality is unidirectional taking the level of significance to 5 percent. This study found that there is a unidirectional causal relationship between change in the gross domestic product to change in transportation capital and change in transportation recurrent to change transportation capital at 5 percent level of significance (see Table 5).

\section{Regression analysis}

Since all the variables for the analysis showed the stationarity nature, the next step was to analyse the potential relationship between the dependent variable and independent variables using the Ordinary Least Square (OLS) model.

Table 6: Estimation of regression result

\begin{tabular}{lllll}
\hline Variable & Coefficient & Std. Error & t-Statistic & Prob. \\
\hline C & 0.065780 & 0.009645 & 6.820156 & 0.0000 \\
LNTC & -0.543442 & 0.210738 & -2.578760 & 0.0151 \\
LNTR & -0.075328 & 0.025610 & -2.941369 & 0.0062 \\
\hline
\end{tabular}

R-squared $=0.321957$, Adjusted R-squared $=0.276754, \mathrm{DW}=2.184797$, Probability: 0.002943

Regression analysis was employed to explore the relationships and to find the degree of impact of the variables on economic growth in the context of Nepal. As shown in Table 6, multiple regression analysis generated a coefficient of determination $R^{2}$ of 0.3219 . Thus, approximately $32 \%$ of the systematic variation in GDP is explained by changes in the independent variables, indicating a good fit, and $68 \%$ of the methodical variation in GDP is not explained by the model. This cause may be attributed to the error term or residual error. Moreover, the Durbin Watson value of 2.1847 is greater than the R-square value of 0.3219 , which implies that the overall model is significant and well fit at the $5 \%$ level of significance. Also, the test shows that there is a negative effect of the variables in Economic growth. One unit rise in the Expenditure of Transportation Capital tends to 
decrease the Economic Growth by 0.543 units. Similarly, one unit rise in Transportation recurrent expenditure affects Economic growth by 0.075 units (see Table 6).

\section{Residual diagnostics}

There are various tests for residual diagnosis, among them, a normality test was used. Normality tests are conducted to ensure that the results may not bring biased conclusions. Before further analysis of the main variables in this study, such as RTR and economic growth using GDP as the dependent variable, a normality test was conducted. The analysis of the frequencies revealed that the scores for skewness and kurtosis were below the suggested cut off scores of 2 and 10, respectively. Moreover, as shown in Figure 3 below, histogram analysis indicated that the data were normally distributed. Thus, further analysis was performed using parametric tests. The JarqueBera statistic was 1.1216, and its corresponding p-value was higher than the significance level of 0.05 ; thus, we cannot reject the null hypothesis, and the error terms are normally distributed (see Figure 3).

Figure 3: Normality test

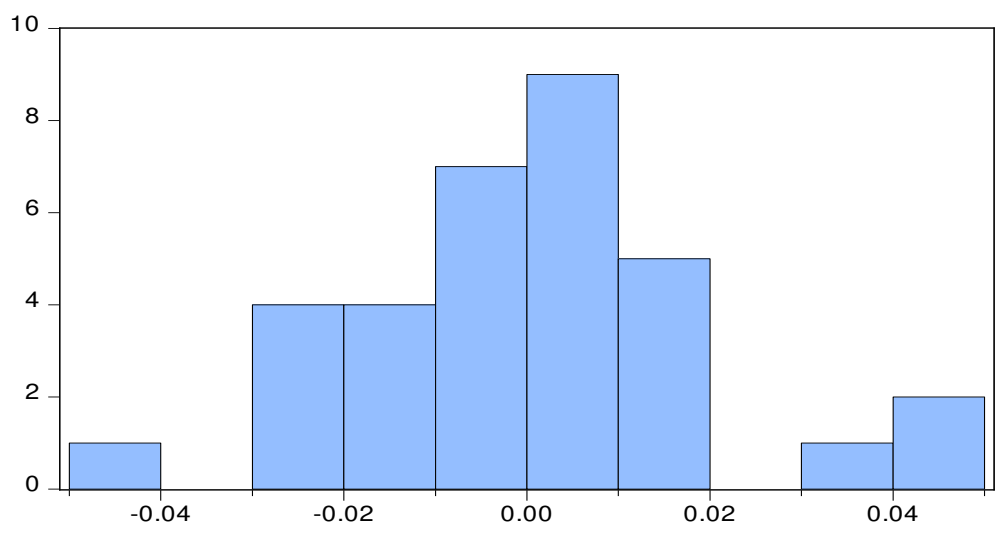

$\begin{array}{lr}\text { Series: Residuals } \\ \text { Sample 1976 } 2008 \\ \text { Observations } 33 \\ \text { Mean } & -4.10 \mathrm{e}-18 \\ \text { Median } & 0.000663 \\ \text { Maximum } & 0.048484 \\ \text { Minimum } & -0.042425 \\ \text { Std. Dev. } & 0.019347 \\ \text { Skewness } & 0.420939 \\ \text { Kurtosis } & 3.327078 \\ & \\ \text { Jarque-Bera } & 1.121640 \\ \text { Probability } & 0.570741\end{array}$

\section{Conclusion}

Maintaining economic growth through government investment in the transportation sector is crucial. Although various plans and policies are directed and pride projects are in the process of execution, the economic growth has not been positively affected by transportations expenditure. Though capital sector investment shows a high degree of significance it has affected negatively and the recurrent expenditure on this sector has a negative effect. This article articulates that both economic growth and recurrent expenditure can simultaneously develop the transportation capital expenditure unidirectionally. Furthermore, attaining economic growth by developing the transportation sector is intricate and formidable, but possible. However, the Vision of the $15^{\text {th }}$ plan 'Happy Nepali and Prosperous Nepal' cannot be fully achieved unless the plan for the transportation sector is fully implemented. For this, more productive investment is, therefore, required in the transportation sector. Higher investment alone cannot contribute to sustainable transportation sector development. Effective and efficient implementation of the expenditure is essential and decisive. 


\section{References}

Aryal, T. (2011). The relationship between public expenditure and economic growth [Unpublished master's thesis]. Tribhuvan University.

Baral, A. (2017, September 20). Road of Nepal: Hulaki Rajmarga. https://bit.ly/3kC652P

Barro, R. J., \& Sala-I-Martin, X. (1992). Public finance in models of economic growth. The Review of Economic Studies, 59(4), 645-661. https://doi.org/10.2307/2297991

Bhagat, S. (2017). Situation of land transportation in Nepal. Tribhuvan University Journal, 31(1-2), 193-206. https://doi.org/10.3126/tuj.v31i1-2.25355

Dahal, P. K., Dahal, L., Khanal, S., Poudel, S., \& Khatiwada, B. (2014). Environmental impact assessment of Kathmandu Terai Fast-Track. International Journal of Environment, 3(4), 1-11. https://doi.org/10.3126/ ije.v3i4.11726

De, U. K., \& Dkhar, D. S. (2018). Public expenditure and agricultural production in Meghalaya, India: An application of bounds testing approach to co-integration and error correction model. International Journal of Environmental Sciences \& Natural Resources, 8(2), 1-8. https://dx.doi.org/10.2139/ ssrn.3637238

Dhungel, B., \& Bista, R. (2015). Economic theory and applications. Dhaulagiri Books and Stationery.

Dickey, D. A., \& Fuller, W. A. (1979). Distribution of the estimators for autoregressive time series with a unit root. Journal of the American Statistical Association, 74(366a), 427-431. https://doi.org/10.1080/0162 1459.1979.10482531

Ebiringa, O. T., \& Charles-Anyaogu, N. B. (2012). Impact of government sectorial expenditure on the economic growth of Nigeria. International Journal of Economic Research, 3(6), 82-92. https://bit.ly/3kREuen

Ghali, K. (1997). Government spending and economic growth in Saudi Arabia. Journal of Economic Development, 22(2), 165-72.

Johansen, S. (1988). Statistical analysis of cointegration vectors. Journal of Economic Dynamics and Control, 12(2-3), 231-254. https://doi.org/10.1016/0165-1889(88)90041-3

Kanel, D. R. (1988). Public expenditure in Nepal: Growth, pattern, and impact. Sterling Publishers.

Koirala, B. (2017, November 13). Construction of Pokhara regional international airport begins. The Himalayan Times. https://bit.ly/3fjK6wy

Ministry of Physical Planning and Works. (2015). EOI for detailed survey and design of electrified railway line. http://mopit.gov.np/noticefile/EOI_Bardibas_Kakarbhitta_Doc_latest_1558853537.pdf

National Planning Commission. (2011). Preparation of detailed project report of Puspalal (Mid Hill) highway project. Government of Nepal.

Nepal Rastra Bank. (2017a). A hand-book of government finance statistics (Vol. 5). https://bit.ly/2IKuC9a

Nepal Rastra Bank. (2017b). Quarterly economic bulletin. https://bit.ly/3lffz4s

Nepal Rastra Bank. (2017c). Current macroeconomic and financial situation.

Nurudeen, A., \& Usman, A. (2010). Government expenditure and economic growth in Nigeria, 1970-2008: A disaggregated analysis. Business and Economics Journal, 2010(4), 1-11. https://bit.ly/3flwQrC

Okoro, A. S. (2013). Government spending and economic growth in Nigeria (1980-2011). Global Journal of Management and Business Research, 13(5), 21-30. https://bit.ly/2UM4Ljv

Pettinger, T. (2018). The Rahn Curve - economic growth and level of government spending. https://www. economicshelp.org/blog/447/economics/the-rahn-curve-economic-growth-and-level-of-spending/

Pathak, A. (2018). Gautam Buddha international airport project expected to be complete within a year. https://bit.ly/35BLGGT

Rutkowski, A. (2009). Public investment, transport infrastructure and growth in Poland. ECFIN Country Focus, 6(11), 1-6. https://bit.ly/2IOlsHq

Sahayogee, J. (2019). Second international airport in Nepal at Nijgadh, Bara. Imperial. https://bit.ly/36YOGwq Shikha, D. (2016, October 21). Quora. https://bit.ly/2IKuC9a

Shrestha, P. K. (2009). The composition of public expenditure, physical infrastructure and economic growth 
in Nepal. NRB Economic Review, 21, 1-4. https://bit.ly/2UJ1yRX

Shrestha, R. \& Shahi, P. (2014, February 28). East-west electric railway: DPR of Simara-Tamsariya segment gets go-ahead. The Kathmandu Post, p. 6. https://bit.ly/2Hs9YKs

Simiyu, C. N. (2015). Explaining the relationship between public expenditure and economic growth in Kenya using vector error correction model (VECM). International Journal of Economic Sciences, 4(3), 19-38. https://doi.org/10.20472/ES.2015.4.3.002.

Stiglitz, J. E. (2000). Economics of the public sector. Norton \& Company, Inc. https://bit.ly/2J1youo

Verbeck, W. S. (2000). The nature of government expenditure and its impact on sustainable economic growth. Middle Eastern Finance and Economics Journal, 4(3), 25-56. https://dx.doi.org/10.22495/ rgcv7i2c1p2

Wegrich, K. (2014). Public sector. In Encyclopedia Britannica Online. https://bit.ly/2IOJ1kw

Xayavong, V. (2007). A macro-econometric analysis of foreign aid in economic growth and development in least developed countries: A case study of the Lao people's democratic republic (1978-2001) [Unpublished doctoral thesis]. Massey University.

Younis, F. (2014). Significance of infrastructure investment for economic growth. https://bit.ly/2IM303F 